\title{
Article \\ Leaching of Copper from Waste-Printed Circuit Boards (PCBs) in Sulfate Medium Using Cupric Ion and Oxygen
}

\author{
Yujin Park ${ }^{1}$, Yuik Eom ${ }^{1}$, Kyoungkeun Yoo ${ }^{1, * \mathbb{D}}$ and Manis Kumar Jha ${ }^{2}$ \\ 1 Department of Energy and Resources Engineering, Korea Maritime and Ocean University (KMOU), \\ Busan 49112, Korea; ujin2020@g.kmou.ac.kr (Y.P.); yuikeom@g.kmou.ac.kr (Y.E.) \\ 2 Metal Extraction and Recycling Division, CSIR-National Metallurgical Laboratory, \\ Jamshedpur 831007, India; mkjha@nmlindia.org \\ * Correspondence: kyoo@kmou.ac.kr; Tel.: +82-51-410-4686
}

check for updates

Citation: Park, Y.; Eom, Y.; Yoo, K.; Jha, M.K. Leaching of Copper from Waste-Printed Circuit Boards (PCBs) in Sulfate Medium Using Cupric Ion and Oxygen. Metals 2021, 11, 1369. https://doi.org/10.3390/met11091369

Academic Editors: Srecko Stopic and Jean François Blais

Received: 29 July 2021

Accepted: 27 August 2021

Published: 30 August 2021

Publisher's Note: MDPI stays neutral with regard to jurisdictional claims in published maps and institutional affiliations.

Copyright: (c) 2021 by the authors. Licensee MDPI, Basel, Switzerland. This article is an open access article distributed under the terms and conditions of the Creative Commons Attribution (CC BY) license (https:// creativecommons.org/licenses/by/ $4.0 /)$.

\begin{abstract}
In the present paper, the leaching of copper from printed circuit boards (PCBs) using sulfuric acid with $\mathrm{Cu}^{2+}$ and $\mathrm{O}_{2}$ is proposed. The effects of various process parameters such as agitation speed, temperature, the type and the flow rate of gas, initial $\mathrm{Cu}^{2+}$ concentration, and pulp density were investigated to examine the dissolution behavior of $\mathrm{Cu}$ from PCBs in $1 \mathrm{~mol} / \mathrm{L}$ sulfuric acid. The kinetic studies were performed using the obtained leaching data. The leaching rate of $\mathrm{Cu}$ from PCBs was found to be higher on addition of $\mathrm{Cu}^{2+}$ and $\mathrm{O}_{2}$ to the leachant in comparison with the addition of $\mathrm{O}_{2}$ or both $\mathrm{Cu}^{2+}$ and $\mathrm{N}_{2}$ in the leachant. The leaching efficiency of $\mathrm{Cu}$ was found to be increased with increasing agitation speed, temperature, $\mathrm{O}_{2}$ flow rate, and initial $\mathrm{Cu}^{2+}$ concentration and decreasing pulp density. The $96 \%$ of $\mathrm{Cu}$ leaching efficiency was obtained under the following conditions: sulfuric acid concentration, $1 \mathrm{~mol} / \mathrm{L}$; temperature, $90{ }^{\circ} \mathrm{C}$; agitation speed, $600 \mathrm{rpm}$; pulp density, $1 \%$; initial $\mathrm{Cu}^{2+}$ concentration, $10,000 \mathrm{mg} / \mathrm{L}$; and $\mathrm{O}_{2}$ flow rate, $1000 \mathrm{cc} / \mathrm{min}$. The leaching data and analyses indicate that the $\mathrm{Cu}$ leaching from PCBs followed the reaction-controlled model satisfactorily and determined that the activation energy was found to be $23.8 \mathrm{~kJ} / \mathrm{mol}$. Therefore, these results indicate that the sulfuric acid solution with $\mathrm{Cu}^{2+}$ and $\mathrm{O}_{2}$ as a mild leach medium without strong oxidants such as $\mathrm{HNO}_{3}, \mathrm{H}_{2} \mathrm{O}_{2}$, and $\mathrm{Fe}^{3+}$ is valid for $\mathrm{Cu}$ leaching from PCBs.
\end{abstract}

Keywords: $\mathrm{Cu}$ leaching improvement; printed circuit boards (PCBs); sulfuric acid; cupric ion; oxygen

\section{Introduction}

Printed circuit boards (PCBs) are core parts of electric and electronic equipment (EEE) [1-5]. The market of PCBs in Korea grew to 13 trillion Korean won by 2016, and 60\% of waste PCBs was recycled, while the rest was exported as used PCBs [6]. Waste PCBs have hazardous pollutants as well as valuable resources, which were recovered by smelters in Korea. However, only three smelters are in operation in Korea, and there is an increasing concern about hazardous gas emission from smelters.

Hydrometallurgical recycling processes have been recognized as alternative methods; generally, the processes consist of pretreatment (liberation), leaching, purification, and electrowinning. Some wastes need pretreatment such as grinding for liberation, which could facilitate contact between leaching reagent and metal components [1]. Even recently, a number of pretreatments and leaching processes for waste PCBs recycling have been proposed, such as the following examples. The pretreatment processes such as soaking in $\mathrm{NaOH}$ solution [7] and microwave pyrolysis [8] and mineral processing processes [9] such as flotation [10] were investigated to enhance the dissolution efficiency of valuable metals from PCBs. Leaching processes of PCBs have been examined using hydrogen peroxide $\left(\mathrm{H}_{2} \mathrm{O}_{2}\right)$ [11-14], ammonia solution [10,14-16], $\mathrm{HNO}_{3}$ [16-18], halogen $[16,17,19,20]$, glycine [12,13], and ionic liquid [21]. Bacterial leaching processes of PCBs have also been reported as environment-benign processes, where Phanerochaete chrysosporium [22], Acidithiobacillus ferrooxidans [23], Leptospirillum ferriphilum or its mixed culture 
with Acidithiobacillus ferrooxidans [24-26], and Frankia sp. [27] were used for Cu leaching. The fact that many processes are still being investigated and tried as above means that bio-hydrometallurgical recycling processes cannot be commercialized easily, despite more than 30 years of research.

The Korean government has also supported the development of hydrometallurgical recycling processes of waste PCBs for small-sized businesses for the last two decades [28]. Several pilot plants of waste PCBs recycling were operated to investigate the feasibility of the pre-treatment followed by hydrometallurgical recycling processes, but they did not reach the demo-plant or commercialization stage for two reasons. Firstly, precious metals, i.e., gold and silver were lost during extensive grinding for liberation and, secondly, capital and environmental costs increased by using nitric acid or hydrogen peroxide as leaching reagents for copper $(\mathrm{Cu})$ dissolution. The amount of copper contained in waste PCBs found to be $5-20 \%[1,29,30]$, and $\mathrm{Cu}$ should be removed or recovered before the precious metal recovery process because $\mathrm{Cu}$ as an impurity could interfere with the recovery of precious metal such as gold [5,31]. Generally, strong oxidants such as $\mathrm{HNO}_{3}, \mathrm{H}_{2} \mathrm{O}_{2}$, and $\mathrm{Fe}^{3+}$ are required to dissolve copper $(\mathrm{Cu})$ from waste $\mathrm{PCBs}$ because the standard electrode potential of copper is $+0.34 \mathrm{~V}\left(\mathrm{Cu}^{2+}+2 \mathrm{e}=\mathrm{Cu}\right)$ [32], which indicates $\mathrm{Cu}$ metal will not be dissolved in sulfuric acid solution.

Conventional oxidants have disadvantages such as $\mathrm{NO}_{\mathrm{x}}$ gas emission due to $\mathrm{HNO}_{3}$ leaching [33-36], increase in reagent consumption due to instability of $\mathrm{H}_{2} \mathrm{O}_{2}$ [37,38], and requirement of additional separation process due to the use of $\mathrm{Fe}^{3+}$ [38-40]. These drawbacks could increase the capital and environmental costs as mentioned above. Therefore, the development of mild leaching condition and minimization in reagent consumption and wastewater generation should be fulfilled for successful hydrometallurgical recycling processes. The use of sulfuric acid-based leaching medium could reduce the capital cost because sulfuric acid is less corrosive than nitric and hydrochloric acids, and sulfuric acid is favorable for purification and electrowinning processes.

In our previous study [40], although a new copper dissolution process in sulfuric acid solution using $\mathrm{Cu}^{2+}$ and $\mathrm{O}_{2}$ was proposed, the leaching tests were carried out to dissolve $\mathrm{Cu}$ from reagent-grade $\mathrm{Cu}$ metal powder. Therefore, in the present study, the leaching tests of PCBs were performed in sulfuric acid solution with $\mathrm{Cu}^{2+}$ and $\mathrm{O}_{2}$ to investigate the effects of agitation speed, temperature, the type and the flow rate of gas, initial $\mathrm{Cu}^{2+}$ concentration, and pulp density for $\mathrm{Cu}$ leaching from PCBs in $1 \mathrm{~mol} / \mathrm{L}$ sulfuric acid solution and, further, activation energy was calculated based on the leaching data and kinetic study.

\section{Materials and Methods}

All waste PCBs were collected from spent hard disk drives of the same model, which were obtained from a recycling company. As shown in Figure 1, the electronic components on the waste PCBs were removed by dissolving solders [1,41], which was achieved by $\mathrm{HCl}$ leaching with $\mathrm{Sn}^{4+}$. The bare waste PCBs were cut with a cutting mill (SM100, Retsch $\mathrm{GmbH} \&$ Co., Haan, Germany) equipped with a $5 \mathrm{~mm}$ sieve, and the product was screened with a $1 \mathrm{~mm}$ sieve. The $1 \mathrm{~mm}$ oversized product was ground further with a mixer mill (MM400, Retsch GmbH \& Co., Haan, Germany). Therefore, all waste PCBs samples with less than $1 \mathrm{~mm}$ were used in the leaching tests. The waste PCBs samples contain $31.7 \%$ of $\mathrm{Cu}$, which was determined by 2-hour aqua-regia digestion (over $100{ }^{\circ} \mathrm{C}$, less than $1 \mathrm{~mm}$ PCBs, and $5 \mathrm{~g}$ PCBs $/ 100 \mathrm{~mL}$ aqua regia) before the leaching tests. All reagents used in this study were of reagent grade. 

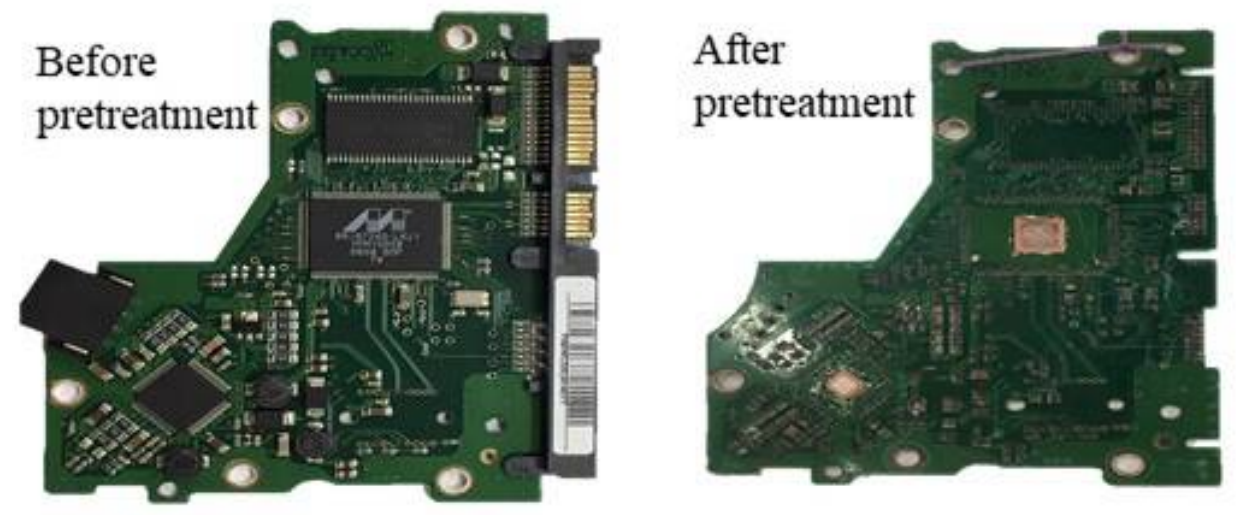

Figure 1. Waste PCBs sample before and after the pretreatment with $\mathrm{HCl}$ and $\mathrm{Sn}^{4+}$.

The leaching tests of the ground waste PCBs were performed in a $500 \mathrm{~mL}$ three-necked Pyrex glass reactor using a heating mantle to maintain the temperature. The reactor was fitted with a reflux condenser and an agitator. The reflux condenser was inserted into one port to avoid solution loss at high temperatures. In a typical run, $200 \mathrm{~mL}$ of $1 \mathrm{~mol} / \mathrm{L}$ sulfuric acid solution with $0,3000,5000,7000$, or $10,000 \mathrm{mg} / \mathrm{L} \mathrm{Cu}^{2+}$ was poured into the reactor with an agitation speed of 200-800 rpm. After the temperature of solution reached the thermal equilibrium $\left(30-90^{\circ} \mathrm{C}\right), 200-1000 \mathrm{cc} / \mathrm{min}$ of oxygen, air, or nitrogen gas was introduced into the reactor and $2 \mathrm{~g}$ of the ground waste PCBs was added to the reactor in all the experiments. During the leaching tests, $3 \mathrm{~mL}$ of the solution was withdrawn periodically at a desired time interval $(15-120 \mathrm{~min})$ by a syringe. The sample was filtered using a $0.45 \mu \mathrm{m}$ membrane filter, and the obtained filtrate was diluted with $5 \% \mathrm{HNO}_{3}$ solution. The leach residue was digested with aqua regia and the solution was diluted with distilled water. The concentration of $\mathrm{Cu}$ was measured using optima 8300 ICP-OES (inductively coupled plasma optical emission spectrometer, PerkinElmer Inc., Waltham, MA, USA). The leaching efficiency of $\mathrm{Cu}$ was calculated using the following equation.

$$
\text { The leaching efficiency of } \mathrm{Cu}(\%)=\mathrm{M}_{\text {solution }} /\left(\mathrm{M}_{\text {solution }}+\mathrm{M}_{\text {residue }}\right) \times 100 \text {, }
$$

where $\mathrm{M}_{\text {solution }}(\mathrm{g})$ and $\mathrm{M}_{\text {residue }}(\mathrm{g})$ represent the mass of $\mathrm{Cu}$ in the leach solution and residue, respectively, and $\mathrm{M}_{\text {solution }}$ does not contain the initial $\mathrm{Cu}^{2+}$, which was added before the leaching tests.

\section{Results and Discussion}

Generally, it has been found that PCBs contain various metals, but the metals, except $\mathrm{Au}$ and $\mathrm{Cu}$, are contained in electronic components such as IC chips, capacitors, and resistors, while $\mathrm{Au}$ and $\mathrm{Cu}$ are distributed in both electronic components and bare PCBs. In the recycling of bare $\mathrm{PCBs}, \mathrm{Cu}$ could act as an impurity in the hydrometallurgical $\mathrm{Au}$ recovery process using cyanide, and $\mathrm{Cu}$ must be removed before the Au recovery from PCBs. Therefore, in this study, the electronic components were removed by $\mathrm{HCl}$ leaching with $\mathrm{Sn}^{4+}$, and then the leaching behaviors of $\mathrm{Cu}$ were investigated as follows.

The leaching tests of $\mathrm{Cu}$ from PCBs were carried out to investigate the effect of $\mathrm{Cu}^{2+}$ and $\mathrm{O}_{2}$ addition on the improvement of $\mathrm{Cu}$ leaching. Figure 2 shows the leaching behaviors of $\mathrm{Cu}$ from PCBs in $1 \mathrm{~mol} / \mathrm{L}$ sulfuric acid solution with or without $10,000 \mathrm{mg} / \mathrm{L} \mathrm{Cu}^{2+}$ at a temperature of $90^{\circ} \mathrm{C}$ and agitation speed of $600 \mathrm{rpm}$ with $1 \%$ pulp density and $1000 \mathrm{cc} / \mathrm{min}$ $\mathrm{N}_{2}$ or $\mathrm{O}_{2}$ introduction. The fastest leaching efficiency of $\mathrm{Cu}$ was obtained by adding both $\mathrm{O}_{2}$ and $\mathrm{Cu}^{2+}$, and when only $\mathrm{O}_{2}$ was introduced in the solution, the leaching efficiency was higher than that with $\mathrm{Cu}^{2+}$ and $\mathrm{N}_{2}$ introduction. In the previous study [40], the mechanism of $\mathrm{Cu}$ leaching with $\mathrm{Cu}^{2+}$ and $\mathrm{O}_{2}$ was explained as follows. The added cupric ion $\left(\mathrm{Cu}^{2+}\right)$ 
oxidizes $\mathrm{Cu}$ metal into cuprous ion $\left(\mathrm{Cu}^{+}\right)$, and then the added $\mathrm{O}_{2}$ oxidizes $\mathrm{Cu}^{+}$ion further into $\mathrm{Cu}^{2+}$. The reactions are expressed in Equations (2) and (3).

$$
\begin{gathered}
\mathrm{Cu}^{2+}+\mathrm{Cu}=2 \mathrm{Cu}^{+} \\
2 \mathrm{Cu}^{+}+\frac{1}{2} \mathrm{O}_{2}+2 \mathrm{H}^{+}=2 \mathrm{Cu}^{2+}+\mathrm{H}_{2} \mathrm{O}
\end{gathered}
$$

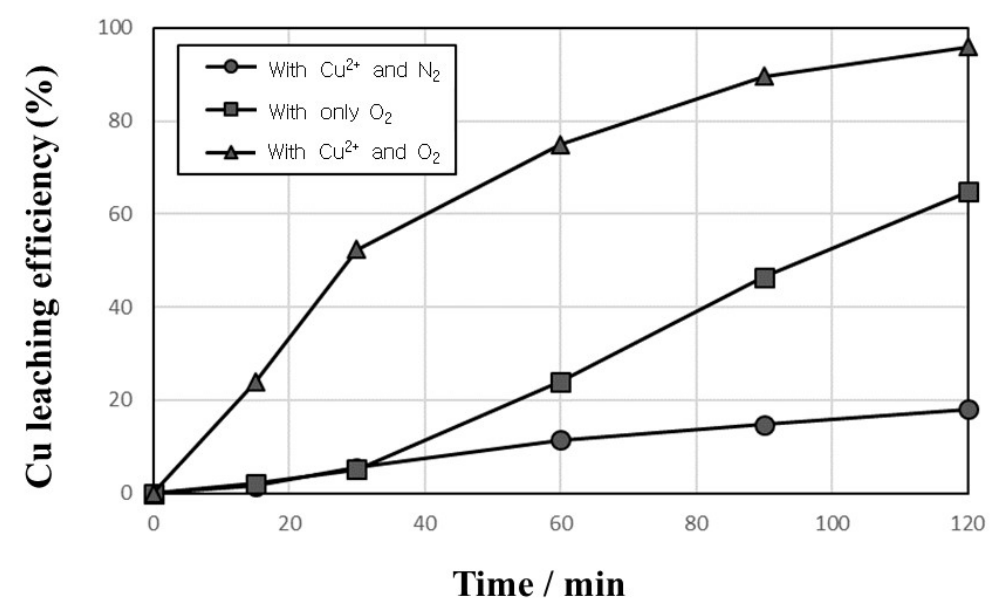

Figure 2. Leaching behaviors of $\mathrm{Cu}$ in $1 \mathrm{~mol} / \mathrm{L}$ sulfuric acid solution with or without $10,000 \mathrm{mg} / \mathrm{L}$ $\mathrm{Cu}^{2+}$ at $90{ }^{\circ} \mathrm{C}$ and $600 \mathrm{rpm}$ with $1 \%$ pulp density and $1000 \mathrm{cc} / \mathrm{min} \mathrm{N}_{2}$ or $\mathrm{O}_{2}$ introduction.

Equations (2) and (3) could be rearranged into Equation (4):

$$
\mathrm{Cu}^{2+}+\mathrm{Cu}+\frac{1}{2} \mathrm{O}_{2}+2 \mathrm{H}^{+}=2 \mathrm{Cu}^{2+}+\mathrm{H}_{2} \mathrm{O},
$$

As shown in Figure 2, when $\mathrm{Cu}^{2+}$ and $\mathrm{N}_{2}$ were added to sulfuric acid solution, the dissolution efficiency of $\mathrm{Cu}$ increased gradually to only $18 \%$. This dissolution would result from partly oxidized surface of $\mathrm{Cu}$ during grinding, and an oxidized part of $\mathrm{Cu}$ could be dissolved in sulfuric acid solution $[30,40]$. When only $\mathrm{Cu}^{2+}$ ions are added without $\mathrm{O}_{2}$, even though $\mathrm{Cu}^{+}$ions are formed, as shown in Equation (2), because $\mathrm{Cu}^{+}$ions are unstable in sulfuric acid solution, the $\mathrm{Cu}^{+}$ions are changed into $\mathrm{Cu}^{2+}$ or $\mathrm{Cu}$ as follows [30]:

$$
2 \mathrm{Cu}^{+}=\mathrm{Cu}^{2+}+\mathrm{Cu},
$$

If no any other oxidant is added in the solution, when one of the two $\mathrm{Cu}^{+}$oxidizes to $\mathrm{Cu}^{2+}$ by losing an electron, the remaining $\mathrm{Cu}^{+}$must reduce to elemental copper $\left(\mathrm{Cu}^{0}\right)$ by receiving the electron. When only $\mathrm{O}_{2}$ is added without $\mathrm{Cu}^{2+}$, the leaching efficiency of $\mathrm{Cu}$ increases gradually, and then increases rapidly after $30 \mathrm{~min}$. Although $\mathrm{Cu}^{2+}$ was not added, because $\mathrm{Cu}$ ions were dissolved out in the beginning of leaching, the $\mathrm{Cu}$ leaching was achieved by $\mathrm{O}_{2}$ addition with a small amount of $\mathrm{Cu}^{2+}$, which was dissolved from PCBs.

As discussed above, $\mathrm{Cu}^{+}$ions are extremely unstable in sulfuric acid solution and it is impossible to detect $\mathrm{Cu}^{+}$as an intermediate in Equations (1) and (2). Therefore, three conditions- $\mathrm{Cu}^{2+} / \mathrm{O}_{2}$ addition, only $\mathrm{O}_{2}$ addition, and $\mathrm{Cu}^{2+} / \mathrm{N}_{2}$ addition-were compared and the synergetic effect of simultaneous addition of $\mathrm{Cu}^{2+}$ and $\mathrm{O}_{2}$ on the improvement of $\mathrm{Cu}$ leaching was confirmed as shown in Figure 2.

Figure 3 shows the effect of agitation speed on the leaching efficiency of $\mathrm{Cu}$ to examine the effect of liquid film boundary diffusion surrounding the solid particles on the dissolution efficiency in $1 \mathrm{~mol} / \mathrm{L}$ sulfuric acid solution at $90^{\circ} \mathrm{C}$ with $10,000 \mathrm{mg} / \mathrm{L} \mathrm{Cu}{ }^{2+}, 1 \%$ pulp density, and $1000 \mathrm{cc} / \mathrm{min}_{2}$ introduction. The dissolution efficiency increased gradually with leaching time, and the higher leaching efficiency was obtained at a higher agitation speed. Similar dissolution behaviors of $\mathrm{Cu}$ were observed in the leaching test with $600 \mathrm{rpm}$ 
and $800 \mathrm{rpm}$. Therefore, in all subsequent leaching tests, a working agitation speed of $600 \mathrm{rpm}$ was selected to provide effective particle suspension in the solution. The effect of temperature $\left(30-90^{\circ} \mathrm{C}\right)$ was investigated in $1 \mathrm{~mol} / \mathrm{L}$ sulfuric acid solution at $600 \mathrm{rpm}$ with $10,000 \mathrm{mg} / \mathrm{L} \mathrm{Cu}^{2+}, 1 \%$ pulp density, and $1000 \mathrm{cc} / \mathrm{min} \mathrm{O}_{2}$ introduction, and the result is presented in Figure 4. The elevated temperatures yielded higher dissolution rates of $\mathrm{Cu}$ from PCBs, and the leaching efficiency of $\mathrm{Cu}$ at $90^{\circ} \mathrm{C}$ increased gradually to $96.0 \%$ within $120 \mathrm{~min}$.

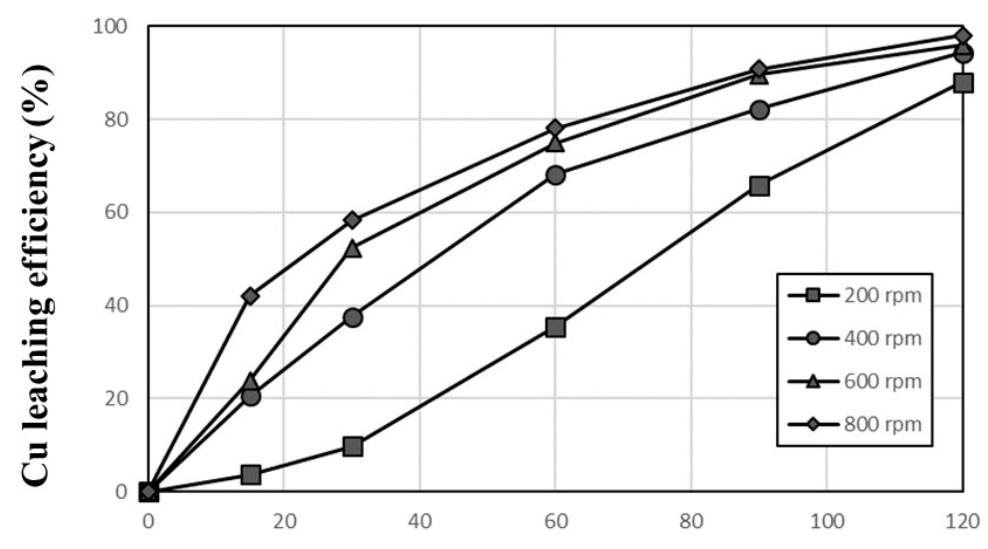

Time / min

Figure 3. Effects of agitation speed on the leaching behaviors of $\mathrm{Cu}$ in $1 \mathrm{~mol} / \mathrm{L}$ sulfuric acid solution at $90{ }^{\circ} \mathrm{C}$ with $10,000 \mathrm{mg} / \mathrm{L} \mathrm{Cu}^{2+}, 1 \%$ pulp density, and $1000 \mathrm{cc} / \mathrm{min}_{2}$ introduction.

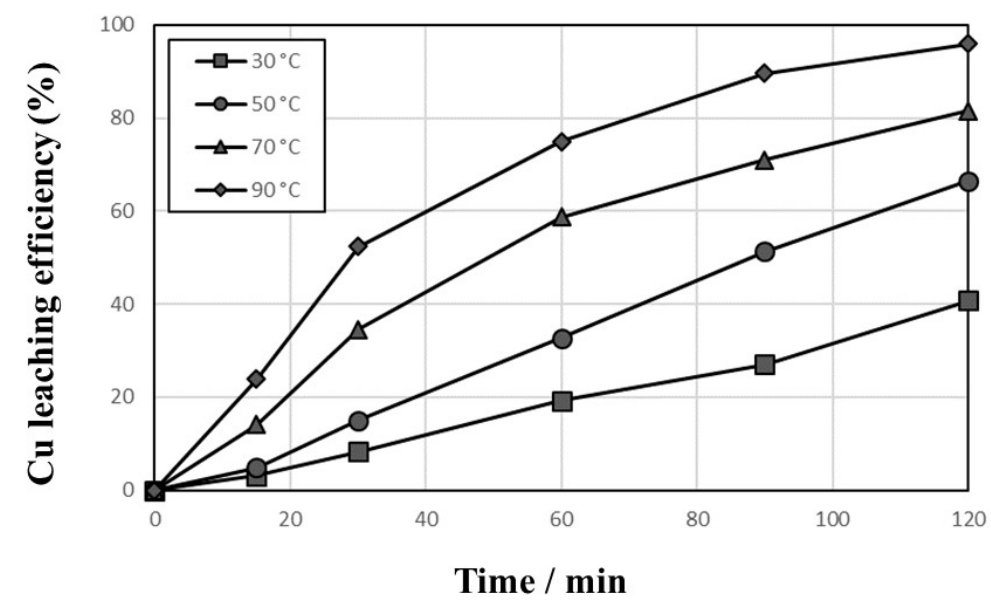

Figure 4. Effects of temperature on the leaching behaviors of $\mathrm{Cu}$ in $1 \mathrm{~mol} / \mathrm{L}$ sulfuric acid solution at $600 \mathrm{rpm}$ with $10,000 \mathrm{mg} / \mathrm{L} \mathrm{Cu}^{2+}, 1 \%$ pulp density, and $1000 \mathrm{cc} / \mathrm{min}_{2}$ introduction.

As discussed above, the leaching of $\mathrm{Cu}$ was improved by adding $\mathrm{Cu}^{2+}$ and $\mathrm{O}_{2}$, where the $\mathrm{O}_{2}$ used in the leaching reaction indicates dissolved oxygen. Generally, the concentration of dissolved oxygen in water decreases with increasing temperature, and the oxygen was introduced continuously into the reactor during the leaching tests. The effect of the $\mathrm{O}_{2}$ gas flow rate was investigated in $1 \mathrm{~mol} / \mathrm{L}$ sulfuric acid solution at $90{ }^{\circ} \mathrm{C}$ and $600 \mathrm{rpm}$ with $10,000 \mathrm{mg} / \mathrm{L} \mathrm{Cu}^{2+}, 1 \%$ pulp density, and $200-1000 \mathrm{cc} / \mathrm{min}_{2}$ introduction. The results presented in Figure 5 indicate that the leaching efficiencies of $\mathrm{Cu}$ increased gradually up to $95 \%$ in all flow rates, but the tests with less than $400 \mathrm{cc} / \mathrm{min}$ showed a slower leaching rate. As oxygen plays a role of oxidant for the oxidation of cuprous ion $\left(\mathrm{Cu}^{+}\right)$to cupric ion $\left(\mathrm{Cu}^{2+}\right)$, as shown in Equation (4), it is important to provide sufficient oxygen into the leaching system. Therefore, $1000 \mathrm{cc} / \mathrm{min}$ flow rate of oxygen was selected in further leaching tests. 


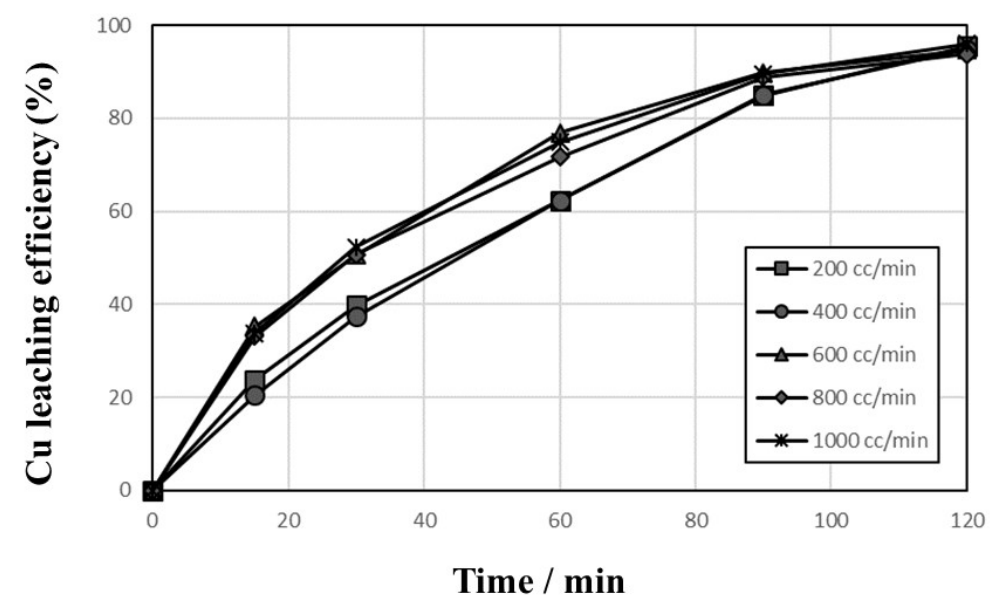

Figure 5. Effects of $\mathrm{O}_{2}$ gas flow rate on the leaching behaviors of $\mathrm{Cu}$ in $1 \mathrm{~mol} / \mathrm{L}$ sulfuric acid solution at $90{ }^{\circ} \mathrm{C}$ and $600 \mathrm{rpm}$ with $10,000 \mathrm{mg} / \mathrm{L} \mathrm{Cu}^{2+}, 1 \%$ pulp density, and $200-1000 \mathrm{cc} / \mathrm{min}_{2}$ introduction.

Leaching experiments were carried out to investigate the effect of initial cupric ion concentration as an oxidant for the dissolution of $\mathrm{Cu}$ metal in $1 \mathrm{~mol} / \mathrm{L}$ sulfuric acid solution, temp. $90{ }^{\circ} \mathrm{C}$, agitation speed $600 \mathrm{rpm}, \mathrm{Cu}^{2+}$ concentration $0-10,000 \mathrm{mg} / \mathrm{L}$, pulp density $1 \%$, and flow rate of $\mathrm{O}_{2}$ in solution $1000 \mathrm{cc} / \mathrm{min}$. Equation (4) represents the chemical reaction of $\mathrm{Cu}$ leaching, where $\mathrm{Cu}^{2+}$ ion acts as an oxidant for the dissolution of $\mathrm{Cu}$ metal. Figure 6 indicates that the leaching efficiencies of $\mathrm{Cu}$ increased gradually with time and the $\mathrm{Cu}^{2+}$ concentration; therefore, the use of $\mathrm{Cu}^{2+}$ is favorable for $\mathrm{Cu}$ metal leaching in sulfuric acid solution. When no $\mathrm{Cu}^{2+}$ was added to the leaching system $\left(0 \mathrm{mg} / \mathrm{L}\right.$ initial $\mathrm{Cu}^{2+}$ in Figure 6), the leaching efficiency of $\mathrm{Cu}$ increased up to $64.7 \%$ and was comparatively slower. As discussed above, partly oxidized $\mathrm{Cu}$ could be dissolved in sulfuric acid solution and the dissolved $\mathrm{Cu}$ ions could act as an oxidant for $\mathrm{Cu}$ metal leaching.

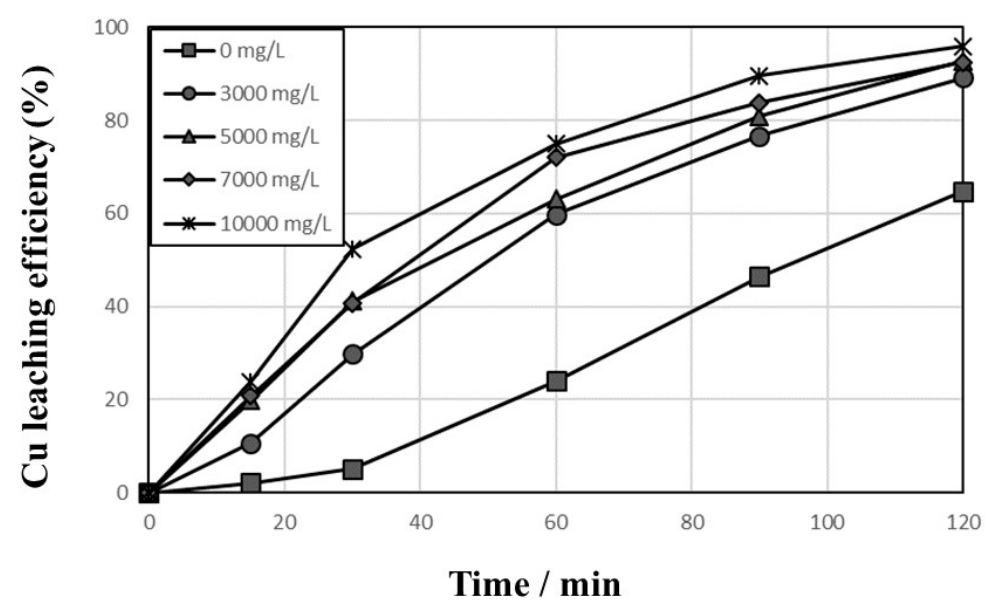

Figure 6. Effects of initial $\mathrm{Cu}^{2+}$ concentration on the leaching behaviors of $\mathrm{Cu}$ in $1 \mathrm{~mol} / \mathrm{L}$ sulfuric acid solution at $90{ }^{\circ} \mathrm{C}$ and $600 \mathrm{rpm}$ with $0-10,000 \mathrm{mg} / \mathrm{L} \mathrm{Cu}^{2+}, 1 \%$ pulp density, and $1000 \mathrm{cc} / \mathrm{min} \mathrm{O}_{2}$ introduction.

In Figure 7, the effects of pulp density on the leaching behaviors of $\mathrm{Cu}$ were investigated in $1 \mathrm{~mol} / \mathrm{L}$ sulfuric acid solution at a temp. of $90^{\circ} \mathrm{C}$ and agitation rate of $600 \mathrm{rpm}$ with $\mathrm{Cu}^{2+}$ concentration $10,000 \mathrm{mg} / \mathrm{L}$, pulp density $1-5 \%$, and flow rate of $\mathrm{O}_{2}$ addition $1000 \mathrm{cc} / \mathrm{min}$. The leaching efficiency of $\mathrm{Cu}$ increased rapidly with the decreasing pulp density. The leaching efficiency with $1 \%$ pulp density increased slower in the beginning of leaching than that with $3 \%$ pulp density, but they show similar leaching behaviors after $60 \mathrm{~min}$. The leaching efficiency with 5\% pulp density was retarded. If all $\mathrm{Cu}$ metals in the PCBs samples dissolved, the Cu concentrations of sample were found to be $3170 \mathrm{mg} / \mathrm{L}$, 
$9510 \mathrm{mg} / \mathrm{L}$, and 15,850 mg/L at 1\%, 3\%, and 5\% pulp density, respectively. In Equation (4), $1 \mathrm{~mol}$ of $\mathrm{Cu}^{2+}$ should be required to oxidize $1 \mathrm{~mol}$ of $\mathrm{Cu}$ metal (the stoichiometric mole ratio is 1). Because the initial $\mathrm{Cu}^{2+}$ concentration was $10,000 \mathrm{mg} / \mathrm{L}$, in the case of $5 \%$ pulp density, the initial $\mathrm{Cu}^{2+}$ concentration was not enough to oxidize all the $\mathrm{Cu}$ metal from PCBs samples, but the dissolved $\mathrm{Cu}$ could be changed into $\mathrm{Cu}^{2+}$ ion, as shown in Equation (4), and the leaching efficiency with 5\% increased to $85.8 \%$ in $120 \mathrm{~min}$, even though it was slow.

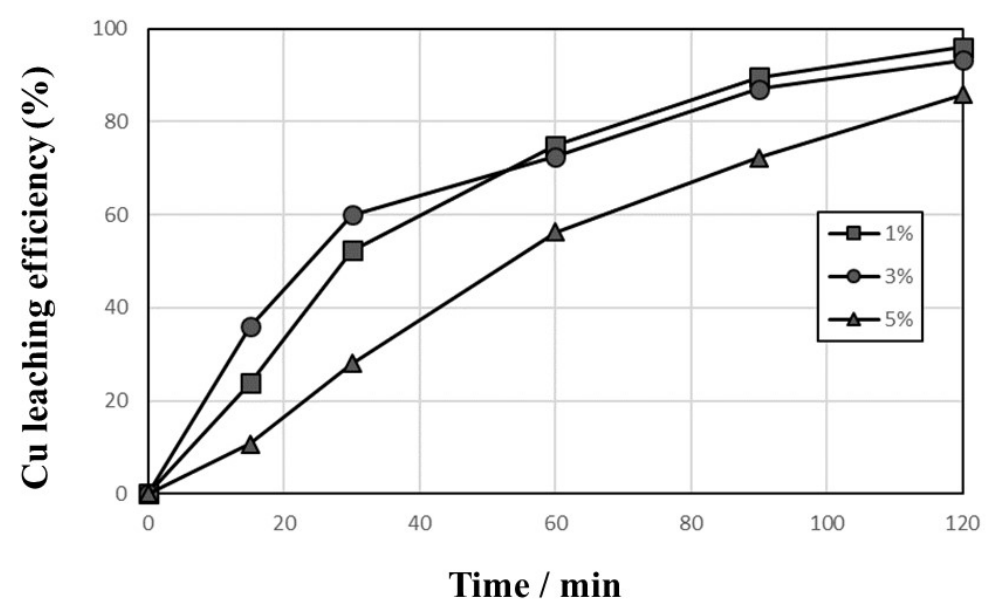

Figure 7. Effects of pulp density on the leaching behaviors of $\mathrm{Cu}$ in $1 \mathrm{~mol} / \mathrm{L}$ sulfuric acid solution at $90{ }^{\circ} \mathrm{C}$ and $600 \mathrm{rpm}$ with $10,000 \mathrm{mg} / \mathrm{L} \mathrm{Cu}^{2+}, 1-5 \%$ pulp density, and $1000 \mathrm{cc} / \mathrm{min}_{2}$ introduction.

Studies on the leaching kinetics of $\mathrm{Cu}$ from PCBs were reported previously and investigations were carried out using $\mathrm{HCl}$ solution with $\mathrm{Cl}_{2}$ [42], $\mathrm{NH}_{4} \mathrm{OH}$ solution with $\mathrm{H}_{2} \mathrm{O}_{2}$ [14], $\mathrm{HNO}_{3}$ solution [43], and $\mathrm{H}_{2} \mathrm{SO}_{4}$ solution with $\mathrm{Fe}^{3+}$ [44]. Activation energy values were calculated using shrinking core model [14,42-44] and were determined to be 20.7-24.5 kJ/mol in $\mathrm{HCl}$ solution with $\mathrm{Cl}_{2}$ [42], $47.39 \mathrm{~kJ} / \mathrm{mol}$ in $\mathrm{NH}_{4} \mathrm{OH}$ solution with $\mathrm{H}_{2} \mathrm{O}_{2}$ [14], $23.35 \mathrm{~kJ} / \mathrm{mol}$ in $\mathrm{HNO}_{3}$ solution [43], and $14.87 \mathrm{~kJ} / \mathrm{mol}$ in $\mathrm{H}_{2} \mathrm{SO}_{4}$ solution with $\mathrm{Fe}^{3+}[44]$, respectively. The shrinking core model can be presented by [45]

$$
\begin{gathered}
1-(1-x)^{\frac{1}{3}}=k_{r} t \\
1-\frac{2}{3} x-(1-x)^{\frac{2}{3}}=k_{d} t
\end{gathered}
$$

where Equation (6) represents the shrinking core model basically based on the surface chemical reaction (reaction-controlled model), while Equation (7) is based on the diffusion reaction (diffusion-controlled model). The value for $x$ in the equations represents the fraction reacted and is obtained from the leaching efficiencies, while $k_{r}$ and $k_{d}$ are rate constants.

The data in Figure 4 were fitted to the models as shown in Figure 8 (reaction-controlled model) and Figure 9 (diffusion-controlled model). The correlation coefficients $\left(\mathrm{R}^{2}\right)$ are 0.9768 to 0.9879 in Figure 8 and 0.8019 to 0.9774 in Figure 9, respectively, which indicate that the reaction-controlled model is more suitable to this leaching behavior than the diffusioncontrolled model. Generally, PCB has a multi-layered structure composed of copper foil and resin. However, as shown in Figure 10, because the copper in PCBs was exposed during extensive milling with cutting and mixer mills, the reaction-controlled model is suitable for this PCBs' leaching. Rate constants $(k)$ for different temperature were calculated by plotting Figure 8, and the Arrhenius plots using the rate constants over $\mathrm{T}^{-1}$ are presented in Figure 11, where the activation energy is found to be $23.8 \mathrm{~kJ} / \mathrm{mol}$. The activation energy is similar to the data reported in conventional studies [14,42-44], which indicate that the leachate containing sulfuric acid with $\mathrm{Cu}^{2+}$ is effective for $\mathrm{Cu}$ leaching. 


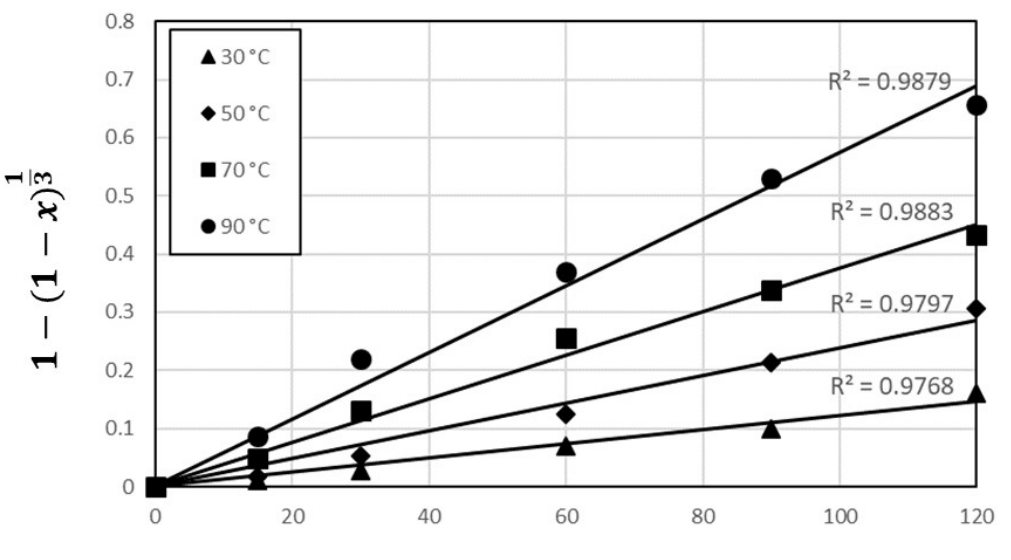

Time / min

Figure 8. Plot of $1-(1-x)^{1 / 3}$ vs. T as a function of time for $\mathrm{Cu}$ leaching at temperature $30-90{ }^{\circ} \mathrm{C}$ in $1 \mathrm{~mol} / \mathrm{L}$ sulfuric acid solution.

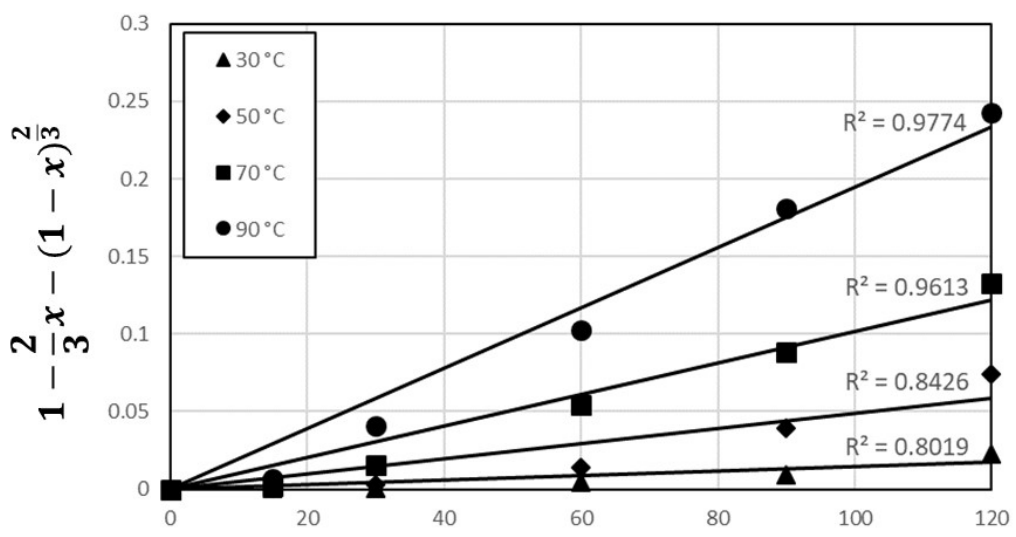

Time / min

Figure 9. Plot of $1-2 / 3 x-(1-x)^{2 / 3}$ vs. T as a function of time for $\mathrm{Cu}$ leaching at temperature $30-90{ }^{\circ} \mathrm{C}$ in $1 \mathrm{~mol} / \mathrm{L}$ sulfuric acid solution.
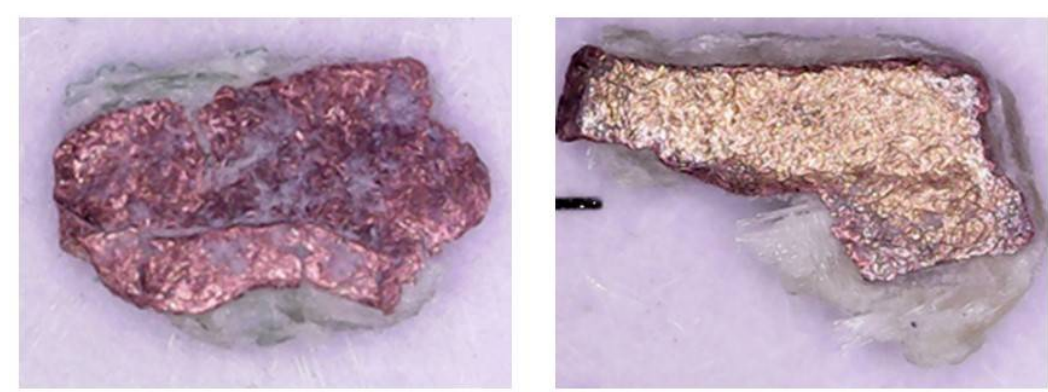

Figure 10. Photos of ground PCBs used in the leaching tests. 


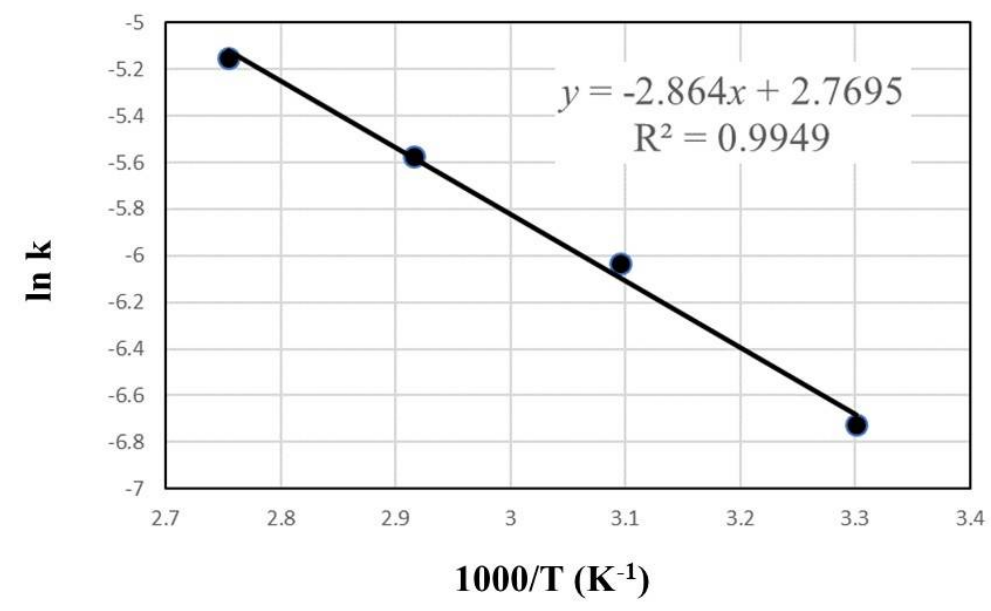

Figure 11. Arrhenius plot for $\mathrm{Cu}$ leaching in $1 \mathrm{~mol} / \mathrm{L}$ sulfuric acid solution.

\section{Conclusions}

Mild leaching conditions using $\mathrm{Cu}^{2+}$ and $\mathrm{O}_{2}$ in sulfuric acid solution were investigated to leach $\mathrm{Cu}$ from PCBs. When $\mathrm{Cu}^{2+}$ and $\mathrm{O}_{2}$ were added to the leach solution, the leaching efficiency of $\mathrm{Cu}$ increased faster than that of the leaching test performed without $\mathrm{Cu}^{2+}$ and $\mathrm{O}_{2}$. On the other hand, the simultaneous use of $\mathrm{Cu}^{2+}$ and $\mathrm{O}_{2}$ improved $\mathrm{Cu}$ leaching from PCBs. The leaching efficiency of $\mathrm{Cu}$ increased with the increasing agitation speed, temperature, gas flow rate of $\mathrm{O}_{2}$, and initial $\mathrm{Cu}^{2+}$ concentration and decreasing pulp density. The leaching efficiency of $\mathrm{Cu}$ increased to $96 \%$ in $1 \mathrm{~mol} / \mathrm{L}$ sulfuric acid solution at temperature $90{ }^{\circ} \mathrm{C}$, agitation speed $600 \mathrm{rpm}$, pulp density $1 \%, \mathrm{Cu}^{2+}$ concentration $10,000 \mathrm{mg} / \mathrm{L}$, and $\mathrm{O}_{2}$ introduction flow rate $1000 \mathrm{cc} / \mathrm{min}$. The kinetic data indicate that the leaching behavior of $\mathrm{Cu}$ followed the reaction-controlled model well rather than the diffusion-controlled model, and the activation energy was calculated to be $23.8 \mathrm{~kJ} / \mathrm{mol}$, which is similar to the data reported in the conventional studies. Therefore, these results suggest that the sulfuric acid solution with $\mathrm{Cu}^{2+}$ and $\mathrm{O}_{2}$ addition will be a suitable leaching condition to leach $\mathrm{Cu}$ from PCBs.

Author Contributions: Methodology, Y.P. and K.Y.; writing—original draft preparation, Y.P. and K.Y.; data curation, Y.P., Y.E., and K.Y.; writing - review and editing, K.Y. and M.K.J.; providing ideas, Y.P. and K.Y. All authors have read and agreed to the published version of the manuscript.

Funding: This work was supported by the Technology Innovation Program (or Industrial Strategic Technology Development Program-Development of Material Component Technology) (20011176, Development of Advanced Technology in Hydrometallurgy for High Added Value of Resources Recovery) Funded by the Ministry of Trade, Industry, and Energy (MOTIE, Korea).

Data Availability Statement: Not applicable.

Conflicts of Interest: The authors declare no conflict of interest.

\section{References}

1. Jung, M.; Yoo, K.; Alorro, R.D. Dismantling of electric and electronic components from waste printed circuit boards by hydrochloric acid leaching with stannic ions. Mater. Trans. 2017, 58, 1076-1080. [CrossRef]

2. Kim, E.Y.; Kim, M.S.; Lee, J.C.; Jha, M.K.; Yoo, K.; Jeong, J. Effect of cuprous ions on Cu leaching in the recycling of waste PCBs, using electro-generated chlorine in hydrochloric acid solution. Miner. Eng. 2008, 21, 121-128. [CrossRef]

3. Yoo, J.M.; Jeong, J.; Yoo, K.; Lee, J.C.; Kim, W. Enrichment of the metallic components from waste printed circuit boards by a mechanical separation process using a stamp mill. Waste Manag. 2009, 29, 1132-1137. [CrossRef] [PubMed]

4. Na, H.; Yoo, K.; Jha, M.K.; Tabelin, C.B. The separation of aluminum and stainless-steel scraps using vibrating mixed-size ball bed. Metals 2020, 10, 868. [CrossRef]

5. Bae, M.; Lee, H.; Kim, S.; Yoo, K. Destruction of cyanide and removal of copper from waste printed circuit boards leach solution using electro-generated hypochlorite followed by magnetite adsorption. Metals 2019, 9, 963. [CrossRef]

6. An, H.; Kang, L.; Lee, C.G. Analysis of Commercial Recycling Technology and Research Trend of Printed Circuit Boards in Korea. Resour. Recycl. 2017, 26, 9-18. [CrossRef] 
7. Moyo, T.; Chirume, B.H.; Petersen, J. Assessing alternative pre-treatment methods to promote metal recovery in the leaching of printed circuit boards. Resour. Conserv. Recycl. 2020, 152, 104545. [CrossRef]

8. Huang, Y.F.; Pan, M.W.; Lo, S.L. Hydrometallurgical metal recovery from waste printed circuit boards pretreated by microwave pyrolysis. Resour. Conserv. Recycl. 2020, 163, 105090. [CrossRef]

9. Jeon, S.; Ito, M.; Tabelin, C.B.; Pongsumrankul, R.; Tanaka, S.; Kitajima, N.; Saito, A.; Park, I.; Hiroyoshi, N. A physical separation scheme to improve ammonium thiosulfate leaching of gold by separation of base metals in crushed mobile phones. Miner. Eng. 2019, 138, 168-177. [CrossRef]

10. Zhu, X.N.; Nie, C.C.; Ni, Y.; Zhang, T.; Li, B.; Wang, D.Z.; Qu, S.; Qiao, F.; Lyu, X.; Qiu, J.; et al. Advanced utilization of copper in waste printed circuit boards: Synthesis of nano-copper assisted by physical enrichment. J. Hazard. Mater. 2020, 401, 123294. [CrossRef]

11. Dávila-Pulido, G.I.; Salinas-Rodríguez, A.; Carrillo-Pedroza, F.R.; González-Ibarra, A.A.; Méndez-Nonell, J.; Garza-García, M. Leaching kinetics of electronic waste for the recovery of copper: Rate-controlling step and rate process in a multisize particle system. Int. J. Chem. Kinet. 2020, 53, 379-389. [CrossRef]

12. Han, Y.; Yi, X.; Wang, R.; Huang, J.; Chen, M.; Sun, Z.; Sun, S.; Shu, J. Copper extraction from waste printed circuit boards by glycine. Sep. Purif. Technol. 2020, 253, 117463. [CrossRef]

13. Li, H.; Oraby, E.; Eksteen, J. Extraction of copper and the co-leaching behaviour of other metals from waste printed circuit boards using alkaline glycine solutions. Resour. Conserv. Recy. 2020, 154, 104624. [CrossRef]

14. Oluokun, O.O.; Otunniyi, I.O. Kinetic analysis of $\mathrm{Cu}$ and $\mathrm{Zn}$ dissolution from printed circuit board physical processing dust under oxidative ammonia leaching. Hydrometallurgy 2020, 193, 105320. [CrossRef]

15. El-Nasr, R.S.; Abdelbasir, S.M.; Kamel, A.H.; Hassan, S.S. Environmentally friendly synthesis of copper nanoparticles from waste printed circuit boards. Sep. Purif. Technol. 2020, 230, 115860. [CrossRef]

16. Tan, Q.; Liu, L.; Yu, M.; Li, J. An innovative method of recycling metals in printed circuit board (PCB) using solutions from PCB production. J. Hazard. Mater. 2020, 390, 121892. [CrossRef]

17. Barnwal, A.; Dhawan, N. Recycling of discarded mobile printed circuit boards for extraction of gold and copper. Sustain. Mater. Technol. 2020, 25, e00164. [CrossRef]

18. Tanısalı, E.; Özer, M.; Burat, F. Precious Metals Recovery from Waste Printed Circuit Boards by Gravity Separation and Leaching. Min. Proc. Ext. Met. Rev. 2021, 42, 1-14. [CrossRef]

19. Cui, H.; Anderson, C. Hydrometallurgical Treatment of Waste Printed Circuit Boards: Bromine Leaching. Metals 2020, 10, 462. [CrossRef]

20. Pereira, M.M.; Costa, F.O.; Gomes, R.F.; Rodrigues, M.L.M.; da Silva, G.A.; Leão, V.A. Multivariate study of a novel hydrometallurgical route employing chloride/hypochlorite for leaching silver from printed circuit boards. Chem. Eng. Res. Des. 2020, 163, 115-124. [CrossRef]

21. He, J.; Yang, J.; Tariq, S.M.; Duan, C.; Zhao, Y. Comparative investigation on copper leaching efficiency from waste mobile phones using various types of ionic liquids. J. Clean. Prod. 2020, 256, 120368. [CrossRef]

22. Liu, Q.; Bai, J.F.; Gu, W.H.; Peng, S.J.; Wang, L.C.; Wang, J.W.; Li, H.X. Leaching of copper from waste printed circuit boards using Phanerochaetechrysosporium fungi. Hydrometallurgy 2020, 196, 105427. [CrossRef]

23. Van Yken, J.; Cheng, K.Y.; Boxall, N.J.; Nikoloski, A.N.; Moheimani, N.; Valix, M.; Sahajwalla, V.; Kaksonen, A.H. Potential of metals leaching from printed circuit boards with biological and chemical lixiviants. Hydrometallurgy 2020, 196, 105433. [CrossRef]

24. Erust, C.; Akcil, A.; Tuncuk, A.; Panda, S. Intensified acidophilic bioleaching of multi-metals from waste printed circuit boards (WPCBs) of spent mobile phones. J. Chem. Technol. Biotechnol. 2020, 95, 2272-2285. [CrossRef]

25. Sodha, A.B.; Tipre, D.R.; Dave, S.R. Optimisation of biohydrometallurgical batch reactor process for copper extraction and recovery from non-pulverized waste printed circuit boards. Hydrometallurgy 2020, 191, 105170. [CrossRef]

26. Tong, L.; Zhao, Q.; Kamali, A.R.; Sand, W.; Yang, H. Effect of Graphite on Copper Bioleaching from Waste Printed Circuit Boards. Minerals 2020, 10, 79. [CrossRef]

27. Marappa, N.; Ramachandran, L.; Dharumadurai, D.; Nooruddin, T. Recovery of gold and other precious metal resources from environmental polluted E-waste printed circuit board by bioleaching Frankia. Int. J. Environ. Res. 2020, 14, 165-176. [CrossRef]

28. Cho, B.G.; Cho, Y.J.; Lee, J.C.; Yoo, K. Korea's metal resources recycling research project-valuable recycling. Geosyst. Eng. 2019, 22, 48-58. [CrossRef]

29. Lim, Y.; Kwon, O.H.; Lee, J.; Yoo, K. The ammonia leaching of alloy produced from waste printed circuit boards smelting process. Geosyst. Eng. 2013, 16, 216-224. [CrossRef]

30. Park, I.; Yoo, K.; Alorro, R.D.; Kim, M.S.; Kim, S.K. Leaching of copper from cuprous oxide in aerated sulfuric acid. Mater. Trans. 2017, 58, 1500-1504. [CrossRef]

31. Bae, M.; Lee, H.; Yoo, K.; Kim, S. Copper (I) selective chemisorption on magnetite $\left(\mathrm{Fe}_{3} \mathrm{O}_{4}\right)$ over gold (I) ions in chloride solution with cyanide. Hydrometallurgy 2021, 201, 105560. [CrossRef]

32. Brett, C.M.A.; Brett, A.M.O. Electrochemistry; Oxford University Press Inc.: New York, NY, USA, 1993; pp. $416-419$.

33. Jeon, S.; Park, I.; Yoo, K.; Ryu, H. The effects of temperature and agitation speed on the leaching behaviors of tin and bismuth from spent lead free solder in nitric acid leach solution. Geosyst. Eng. 2015, 18, 213-218. [CrossRef]

34. Kim, S.; Lee, J.C.; Lee, K.S.; Yoo, K.; Alorro, R.D. Separation of tin, silver and copper from waste Pb-free solder using hydrochloric acid leaching with hydrogen peroxide. Mater. Trans. 2014, 55, 1885-1889. [CrossRef] 
35. Yoo, K.; Lee, J.C.; Lee, K.S.; Kim, B.S.; Kim, M.S.; Kim, S.K. Recovery of Sn, Ag and Cu from waste Pb-free solder using nitric acid leaching. Mater. Trans. 2012, 53, 2175-2180. [CrossRef]

36. Yoo, K.; Lee, K.; Jha, M.K.; Lee, J.C.; Cho, K. Preparation of nano-sized tin oxide powder from waste Pb-free solder by direct nitric acid leaching. J. Nanosci. Nanotechnol. 2016, 16, 11238-11241. [CrossRef]

37. Kim, S.K.; Lee, J.C.; Yoo, K. Leaching of tin from waste Pb-free solder in hydrochloric acid solution with stannic chloride. Hydrometallurgy 2016, 165, 143-147. [CrossRef]

38. Lee, S.H.; Yoo, K.; Jha, M.K.; Lee, J.C. Separation of Sn from waste Pb-free Sn-Ag-Cu solder in hydrochloric acid solution with ferric chloride. Hydrometallurgy 2015, 157, 184-187. [CrossRef]

39. Nguyen, T.T.; Yoo, K.; Jha, M.K.; Park, J.; Choi, U.; Choe, H.; Lee, J.C. Removal of heavy metals from tailing in citrate solution with ferric chloride. Mater. Trans. 2018, 59, 1665-1668. [CrossRef]

40. Yoo, K.; Park, Y.; Choi, S.; Park, I. Improvement of Copper Metal Leaching in Sulfuric Acid Solution by Simultaneous Use of Oxygen and Cupric Ions. Metals 2020, 10, 721. [CrossRef]

41. Park, Y.; Yoo, K. Dismantling of Components from Waste Printed Circuit Boards Using Stannic Chloride Solution. Resour. Recy. 2021, 30, 24-30. [CrossRef]

42. Kim, E.Y.; Kim, M.S.; Lee, J.C.; Jeong, J.; Pandey, B.D. Leaching kinetics of copper from waste printed circuit boards by electro-generated chlorine in $\mathrm{HCl}$ solution. Hydrometallurgy 2011, 107, 124-132. [CrossRef]

43. Dutta, D.; Panda, R.; Kumari, A.; Goel, S.; Jha, M.K. Sustainable recycling process for metals recovery from used printed circuit boards (PCBs). Sustain. Mater. Technol. 2018, 17, e00066. [CrossRef]

44. Laubertová, M.; Derin, B.; Trpčevská, J.; Šándorová, K.; Sminčáková, E. Metals Recovery: Study of the Kinetic Aspects of Copper Acidic Leaching Waste Printed Circuit Boards from Discarded Mobile Phones. ActaMontanisticaSlovaca 2019, $24,223-233$.

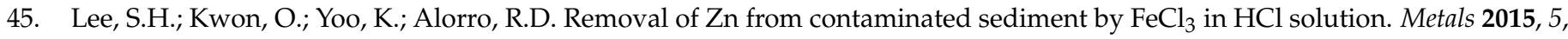
1812-1820. [CrossRef] 